\title{
Crowdfunding Medical Care: A Comparison of Online Medical Fundraising in Canada, the United Kingdom, and the United States
}

Sameh N. Saleh, MD ${ }^{1} *$ - sameh.n.saleh@gmail.com

Ezimamaka Ajufo, BM BCh ${ }^{1}$ - eajufo@gmail.com

Christoph U. Lehmann, MD ${ }^{2,3}$ - christoph.lehmann@utsouthwestern.edu

Richard J. Medford, MD ${ }^{1,2}$ - richard.medford@utsouthwestern.edu

${ }^{1}$ Department of Internal Medicine, University of Texas Southwestern Medical Center, Dallas, TX, United States.

${ }^{2}$ Clinical Informatics, University of Texas Southwestern Medical Center, Dallas, TX, United

States.

${ }^{3}$ Department of Pediatrics, University of Texas Southwestern Medical Center, Dallas, TX, United States.

*Corresponding author

\begin{abstract}
Background: Medical crowdfunding is increasingly used to finance personal healthcare costs in Canada (CAN), United Kingdom (UK), and United States (US) despite major differences in their healthcare systems. Yet, it lacks comparative descriptive research to guide policy changes that can promote equitable and accessible healthcare.

Methods: We conducted a cross-sectional analysis of Canadian, British, and American campaigns between February 2018 and March 2019 on the GoFundMe platform $(n=3,396)$. We extracted and manually reviewed variables from campaigns on each country's GoFundMe discovery webpage, explored campaign characteristics, and compared each country's campaign demographics to its respective national census. We fit multivariate linear regression models for funds raised for the cohort and for each country.

Results: We examined 1,091 Canadian, 1,082 British, and 1,223 American campaigns. US campaigns (median [IQR] \$38,204 [\$31,200 to \$52,123]) raised more funds than those in CAN $(\$ 12,662$ [\$9,377 to $\$ 19,251])$ and the $\operatorname{UK}(\$ 6,285$ [ $\$ 4,028$ to $\$ 12,348])$. Female $(38.4 \%$ of campaigns vs. $50.9 \%$ of US census; $p<0.001)$ and black (5.3\% of campaigns vs. $13.4 \%$ of US census; $\mathrm{p}<0.001)$ beneficiaries were underrepresented in US campaigns. In the full cohort, blacks raised $\$ 4,007$ less $(95 \%$ confidence interval $[C I]-\$ 6,913$ to $-\$ 1,101 ; p=0.007)$ and males raised $\$ 1,742$ more (95\% CI $\$ 583$ to $\$ 2,901 ; \mathrm{p}=0.003$ ) per campaign. Cancer was the most common diagnosis represented overall $(54.5 \%)$. Across all diagnoses, campaigns primarily for routine treatment expenses were three times more common in the United States compared to Canada and the United Kingdom (CAN $21.9 \%$ vs. UK $26.6 \%$ vs. US $77.9 \%$; p $<0.001$ ). However, campaigns with routine care were less successful overall, raising $\$ 4,589$ less per campaign (CI $-\$ 6,429$ to $\$ 2,749 ; \mathrm{p}<0.001)$. Campaigns primarily for alternative treatment expenses were nearly five times as common for cancer $(24 \%)$ than for non-cancer (5\%) diagnoses.

Discussion: The trends observed suggest that there are important gaps in healthcare provision in all of the countries examined across a wide range of diagnoses. Although medical crowdfunding has the potential to provide short-term relief from medical financial burden for a privileged subset of patients, it may carry wider-reaching adverse societal effects including the promotion of racial and gender disparities in healthcare. Further work is needed to inform policy changes that promote equitable and accessible healthcare through this practice.

Funding: None.
\end{abstract}




\section{Introduction}

Crowdfunding, the online solicitation of public donations, has become an important form of financing to pay for accumulated personal healthcare debts. Approximately a third of all crowdfunding campaigns are intended to pay for healthcare-related costs. ${ }^{1-3}$ The growing importance of medical crowdfunding (MCF) is reflected by trends on GoFundMe, the largest social crowdfunding platform in the world. ${ }^{3,4}$. In 2011, medical causes raised \$1.6 million GoFundMe; in 2014, the amount had increased almost a hundredfold to $\$ 150$ million and in 2016, more than $\$ 650$ million. ${ }^{1,3}$

The growing reliance of United States (US) healthcare consumers on MCF is primarily attributed to increasing healthcare costs and the lack of a publicly funded healthcare system. ${ }^{1,5,6}$ However, the popularity of MCF in developed countries with universal healthcare such as Canada (CAN) and the United Kingdom (UK) suggests additional reasons. ${ }^{7-10} \mathrm{MCF}$ has financed an array of experimental and alternative therapies as well as gaps in public services. ${ }^{11-14}$ Despite its growth, there is growing, but limited empirical research on MCF, including research on sociodemographics of beneficiaries and the diagnoses and treatments championed. Moreover, inequity, barriers to access, invasion of privacy, fraud, and dangerous therapies have all been associated with MCF, but are poorly understood. . $^{4,15-19}$

The goal of this study was to evaluate three important aspects of MCF in different healthcare systems: the cause for turning to crowdfunding, characteristics of beneficiaries and campaigns, and factors associated with funding success. We selected GoFundMe as an ideal environment to study. As of 2018, the platform reportedly controlled $90 \%$ of the social crowdfunding market in the US and $80 \%$ of the global market. ${ }^{20}$ We studied consecutive campaigns from GoFundMe in CAN, the UK, and the US, the three countries with the largest markets on this platform.

\section{Methods}

\section{Study Population}

We conducted a cross-sectional analysis of campaigns launched between February 2018 and March 2019 from the GoFundMe domains in CAN, the UK, and the US. GoFundMe offers 21 cause categories for users to select; using a web scraping tool (Beautiful Soup ${ }^{21}$ ), we extracted campaigns from the "Medical" category only. For each country's GoFundMe domain, we accessed the 1,000 available medical campaigns on the "Discover" page (www.gofundme.com/discover/medical-fundraiser) at two timepoints in February 2019 and again 30 days later in March 2019. Our query resulted in 1,107, 1,117, and 1,232 unique campaigns in CAN, the UK, and the US, respectively (Figure 1). We excluded 61 campaigns that did not benefit a unique patient such as those that raised funds for a general cause, research, or non-profit organization.

\section{Study Variables}

For each campaign, we extracted the quantitative data displayed on the campaign webpage including the monetary goal, amount raised to date, number of donors, location, length of the fundraising campaign, Facebook shares, and GoFundMe hearts (the equivalent of webpage "likes"). Data were complete except Facebook shares, with $2.6 \%$ of campaigns missing values, for which we imputed a value of zero. We converted all funds to US dollars based on currency exchange rates on the day we accessed the data. 
Using the text and media on each initial campaign post, a two-person manual review of the campaigns collected data on demographics, diagnosis, type of treatment (routine, experimental [i.e., not yet approved], approved but inaccessible [i.e., unavailable in the patient's location], alternative [i.e., treatments used in lieu of standard care], and unspecified), funding intent of the campaign (primarily for treatment costs), patient location (residing outside of the campaign country), and status (alive or deceased). eAppendix in the Supplement details the variables and definitions used for labeling the columns. Each individual reviewed $55 \%$ of the data with $10 \%$ overlap among the reviewers. Concordance analysis showed the inter-rater reliability $(\kappa)$ exceeded 0.77 for all but one category (eTable 1 in the Supplement). A $\kappa$ greater than 0.8 indicates almost perfect agreement. ${ }^{22}$ There was greater than $89.2 \%$ raw agreement in all categories, with most greater than $98 \%$. A blinded third reviewer adjudicated any discrepancies between the two reviewers.

\section{Statistical Analysis}

SS completed all analysis using Python software, version 3.7.2 (Python Software Foundation). We performed descriptive data analysis of all variables to evaluate trends and common characteristics of MCF in the three countries. Given the non-Gaussian populations, we used Kruskal-Wallis, Chi-squared, and Fischer's exact testing to detect statistical differences among the three groups. To test for representativeness, we compared the campaign demographics to respective national census data (2016 CAN census $^{23}, 2018$ UK estimate $^{24}, 2018$ US estimate $^{25}$ ) using Chi-squared testing.

We performed multivariable linear regressions for the full cohort and by country using funds raised as the prespecified primary outcome and completed a sensitivity analysis for other outcomes. Funds raised has been a common outcome reported and used in MCF research. ${ }^{11,12} \mathrm{We}$ constructed a pairwise Pearson correlation matrix among all variables and excluded repetitive variables with high collinearity from the analysis resulting in the removal of GFM hearts ("likes") and campaign narrative character count from the analysis due to high correlation with the number of donors and narrative word count, respectively. To avoid collinearity in categorical variables, we dropped the least specific variable (e.g. "Other" for diagnosis or "Unspecified" for the treatment type). We further removed the most collinear variables (e.g. "Female" given high collinearity with "Male"). The list of variables included is displayed in Table 3. We evaluated the models using the $\mathrm{R}^{2}$ coefficient and compared variable coefficients with confidence intervals to determine the strength of effect and statistical significance. We did not adjust for multiple comparisons as this was an exploratory study and should be interpreted as hypothesis-generating. Inferences may not be reproducible and further dedicated studies are needed to confirm the results.

\section{Results}

\section{Beneficiary Demographics and Diagnoses}

Of the 3,396 campaigns, 1,091 originated in CAN, 1,082 in the UK, and 1,223 in the US. Table 1 presents the campaign characteristics, stratified by country. Table 2 compares the campaign demographics in each country to its national census. Most campaign beneficiaries were male (52.0\%), adult (76.1\%), and non-black (95.8\%). The US had the highest proportion (59.0\%) of male beneficiaries (CAN vs. US and UK vs. US, both $\mathrm{p}<0.001$ ). Females comprise $50.9 \%$ of the 
US population, but were beneficiaries in only $38.4 \%$ of US campaigns $(\mathrm{p}<0.001)$. In the US, adults were over-represented compared to the census ( $\mathrm{p}=0.003$ ). The US had more black beneficiaries than CAN and a similar proportion to the UK. However, compared to national census representations, black beneficiaries were most underrepresented in the US $(5.3 \%$ vs. $13.4 \%, \mathrm{p}<0.001)$. Black Canadians were also underrepresented (1.9\% vs. $3.5 \%, \mathrm{p}=0.004)$, while blacks in the UK were overrepresented in campaigns $(5.1 \%$ vs. $3.3 \%, \mathrm{p}<0.001)$. Cancer was the most common diagnosis represented in fundraisers $(54.5 \%)$, followed by neurologic $(15.3 \%)$, other (10.4\%), and trauma (9.8\%). Compared to CAN and the UK, the US proportionally had the most campaigns for acute illness, cardiac, and trauma.

\section{Fundraising Characteristics}

Campaigns in this study collectively raised $\$ 92.9$ million accounting for $51.9 \%$ of the total funds sought. Only $33.3 \%$ of all campaigns had met their goal at data extraction. Funds raised ranged from $\$ 2,772$ to $\$ 343,762$ per campaign. US campaigns set higher fundraising goals than those in CAN and the UK. Accounting for $\$ 57.8$ million (62.2\% of the total funds raised), US campaigns raised approximately three times the funds of CAN campaigns $(\mathrm{p}<0.001)$ and six times the funds of UK campaigns $(\mathrm{p}<0.001)$ on average, despite being two months shorter in duration $(\mathrm{p}<0.001)$. US campaigns had significantly more donors and Facebook shares (all $\mathrm{p}<0.001$ ).

\section{Treatment Type}

Figure 2 summarizes the treatment types for which campaigns raised funding, stratified by country. While routine care was the most common treatment type, accounting for $69.4 \%$ of campaigns, $84 \%$ of US campaigns focused on routine care compared to $69 \%$ of CAN campaigns and $54 \%$ of UK campaigns (CAN vs. US and UK vs. US, both $\mathrm{p}<0.001$ ) (Figure 2A).

Experimental, approved but inaccessible, and alternative care were all more common among CAN and UK campaigns compared to US campaigns. The UK had substantially more approved but inaccessible care than CAN $(\mathrm{p}<0.001)$ or the US $(\mathrm{p}<0.001)$. Approximately a third $(\mathrm{n}=1,078)$ of all campaigns were fundraising primarily for treatment expenses. Of these, campaigns funding routine care were approximately three times more common in the US than CAN or the UK (CAN $21.9 \%$ vs. UK $26.6 \%$ vs. US $77.9 \%$, p<0.001) (Figure 2B). Campaigns primarily for treatment expenses in CAN and the UK were similarly distributed among routine, alternative, experimental, and unavailable therapies. Nearly a fourth of cancer campaigns primarily funding treatment were for alternative therapies, while all non-cancer diagnoses combined had less than $5 \%$ (eTable 2 in the Supplement).

\section{Predictors of Campaign Success}

Findings from multivariable regression analysis of funds raised per campaign are presented in Table 3. Campaign country was the strongest predictor of the amount raised for the full cohort. US campaigns raised $\$ 16,930$ more on average ( $p<0.001)$. Campaigning from CAN and the UK yielded $\$ 2,419$ and $\$ 6,769$ fewer funds, respectively ( $<<0.001$ for both). Number of donors and fundraising goal were strongly associated with funding success. Facebook shares were not associated with funding success in the main regression model, but when donor numbers (moderately collinear with Facebook shares) were removed from the model, Facebook shares became associated with funds raised $(\mathrm{p}<0.001)$ [data not shown]. 
Beneficiary race and gender were important predictors of funds raised. Overall, black beneficiaries raised $\$ 4,007$ less per campaign ( $\mathrm{p}=0.007)$. There was a concordant but nonsignificant trend in the country analyses. Male beneficiaries raised $\$ 1,742$ more per campaign than their counterparts $(\mathrm{p}=0.003)$; this trend was most pronounced in CAN where males raised $\$ 2,914$ more $(\mathrm{p}<0.001)$. Campaigns for routine care raised $\$ 4,589$ less per campaign $(\mathrm{p}<0.001)$; this association was strongest in the US with $\$ 11,060$ less per campaign $(\mathrm{p}<0.001)$.

\section{Discussion}

We examined 3,396 medical campaigns from CAN, the UK and the US, the three largest crowdfunding markets on GoFundMe, to characterize MCF beneficiaries, impetus for use of $\mathrm{MCF}$, and determinants of funding success. To our knowledge, this is the largest quantitative analysis of the MCF landscape to date. US campaigns set higher goals and raised several-fold more funds than campaigns in CAN or UK. However, approximately two-thirds of campaigns in each country did not meet their funding goals. In the US, nearly $80 \%$ of campaigns primarily funding treatment were for routine care, while in CAN and the UK, funding for routine care was sought about as frequently as for alternative, approved but inaccessible, and experimental therapies. Campaigns for routine care were associated with less crowdfunding success, while campaigns for experimental therapies raised more funds. Finally, we observed gender and racial inequities among beneficiaries.

\section{Beneficiary demographics and inequities in crowdfunding}

Crowdfunding was initially heralded as a "digital safety net" or a mechanism for democratizing charity where anyone could benefit. ${ }^{7}$ However, anecdotal and empirical evidence suggests that crowdfunding may exacerbate socioeconomic inequities. ${ }^{9,15,26}$ In our study, blacks and females were under-represented in US campaigns and blacks were under-represented in CAN campaigns. In another study of 637 randomly sampled US MCF campaigns from GoFundMe, non-white beneficiaries were also significantly under-represented, constituting only $19 \%$ of the sample while this group represents $27 \%$ of the US census. ${ }^{27}$ Within our sample, females and black beneficiaries raised approximately $\$ 4,000$ and $\$ 1,700$ less than their male and non-black counterparts, respectively. Similarly, in a US study of 850 campaigns for organ transplantation, females had raised $27 \%$ less than males after multivariable adjustment. ${ }^{12}$ In a CAN study of 319 campaigns, being a visible ethnic minority was associated with raising $15 \%$ less in funds, before adjustment for technological competency (using quantity of campaign images, videos, updates, and perks) and $6 \%$ less after adjustments. ${ }^{7}$

Race and gender disparities reflect the pillars on which MCF is dependent: access to technology, literacy, social capital, and perception. Those with socioeconomic disadvantage suffer from the "digital divide" that limits online participation due to a lack of access to information technology (e.g., computer and internet). Writing, media, and healthcare literacies, which reflect socioeconomic privilege, enable an individual to augment his/her "illness narrative", communicate "deservingness", and thereby, generate campaign appeal and influence 4 Furthermore, broader, more affluent social communities and larger social media networks are well-recognized determinants of crowdfunding success. ${ }^{4,72}$ Finally, conscious and unconscious systemic racial and gender biases likely obscure perception of worthiness in MCF campaigns. ${ }^{28}$ Our findings substantiate concerns that MCF facilitates the distribution of resources 
according to biases and preferences favoring an already privileged group of individuals and thus, contribute to widening social inequities. ${ }^{29,30}$

\section{Reasons individuals turn to medical crowdfunding and gaps in healthcare funding} If trends in MCF reflect healthcare cost coverage and insurance ${ }^{7,30}$, this study highlights several country-specific shortcomings in healthcare funding. The trends seen in the US suggest that its greatest systemic funding failure lies in the provision of routine health care. Despite a decrease in the uninsured rate after passage of The Affordable Care Act (ACA), as of 2018, 11.1\% of adults under the age of 65 were uninsured ${ }^{31}$ and $29 \%$ were estimated to be underinsured ${ }^{32}$ (i.e., out-ofpocket costs or deductibles comprising 5-10\% of their income) reflected in the overrepresentation of adult campaigns in the US. Most US campaigns across all diagnoses had routine care suggesting pervasive insufficient insurance coverage in the US. Diagnosis groups with more routine care such as trauma and acute illness were more common in the US. For campaigns primarily funding treatments, $78 \%$ were for routine care in the US compared to approximately $25 \%$ of analogous campaigns in both CAN and the UK. Yet, campaigns for routine care raised $\$ 11,060$ less in the US, perhaps reflecting the saturation of the US MCF market with this type of campaign. US healthcare costs are the highest in the developed world and health insurance deductibles have increased eight times as much as wages since $2008 .{ }^{33}$ The disproportionate solicitation of MCF in the US overall and specifically for routine care likely reflect the high out-of-pocket costs associated with essential healthcare in the US.

The trends seen in CAN and UK reflect the unique failures of publicly funded healthcare systems. Notably, routine care still comprised 22 and $26 \%$ of campaigns primarily funding treatment in CAN and the UK, respectively, pointing to possible gaps despite universal healthcare. These gaps may be driven by rising out-of-pocket medication costs and insurance premiums in CAN and dissatisfaction with wait times for public care in the UK. ${ }^{7,10,34}$ Fundraising for experimental and approved but inaccessible therapies was the purpose of approximately $50 \%$ of campaigns in CAN and the UK highlighting a perceived shortcoming of publicly funded healthcare - insufficient or delayed access to novel and experimental treatments.

For cancer patients, financial hardship is common as novel expensive therapies become the standard of care and survival rates rise. ${ }^{35-37}$ Of the 9.5 million people diagnosed with cancer between 2000 and 2012 in the US, 42.4\% had exhausted their life's financial assets within two years ${ }^{38}$. The enormous scope of unmet financial need in cancer care is reflected in the marked overrepresentation of cancer campaigns on crowdfunding platforms. ${ }^{4,7,14}$ In our cohort, cancer accounted for 50-60\% in all three countries. Notably, amongst cancer campaigns primarily funding treatment, campaigns for alternative therapies (22\%) were at least twice as frequent as other diagnoses examined. Patients may seek alternative therapies for cancer to complement or replace proven treatments either by choice or because they were not available or failed. ${ }^{13}$ The popularity of alternative therapies for cancer creates the potential for unproven and potentially dangerous therapies yielding wasted resources, false hopes, delay of appropriate palliative care, and reduced survival. ${ }^{13,16-18}$

\section{Determinants of crowdfunding success}

Beneficiary demographics, treatment type, the campaigning country, number of donors, fundraising goal, and campaign narrative length were important determinants of funding success. 
Initial regression analysis did not demonstrate a fundraising association with Facebook shares, but further sensitivity analysis that excluded donor numbers from the model, showed a strong association between Facebook shares and funds raised, reflecting moderate collinearity between Facebook shares and donor numbers. Previous crowdfunding research has shown that demographics $^{7,12}$, donor numbers ${ }^{39}$, fundraising goal ${ }^{11,12}$, campaign narrative length ${ }^{11,12,40}$, and social media presence ${ }^{4,7,40}$ are predictors of crowdfunding success. Setting a higher goal for medical campaigns may indirectly communicate depth of need to donors and promote the concept of "deservingness." Campaign narrative length reflects the importance of the illness narrative to funding success. Positive language in the narrative confers a fundraising $\operatorname{advantage}^{12,40}$ while references to the systemic injustices that led to a given MCF campaign are infrequently observed. ${ }^{41}$

\section{Limitations}

This study has several limitations. First, while our dataset is larger than those in previous MCF research, it is only a small subset of popular MCF campaigns. Only campaigns visible on the "Discover" page of GoFundMe were included in our sample, which might have led to a bias towards more successful campaigns. We adopted his approach because it allowed us to filter out dummy or unverifiable campaigns that would have made our analysis unreliable. Further work is needed to explore trends in all campaigns and other factors affecting funding success.

Generalizability of our findings is limited by the use of only one MCF platform. It is difficult to truly ascertain the representation of MCF platforms due to a paucity of historical data and inaccessibility of proprietary information in a commercial market. Second, the veracity of the online data cannot be ensured, which restricts interpretability, but also highlights the important problems of misinformation, pseudoscience, and fraud in MCF. The lack of regulation and oversight raises questions about legal and medical responsibility. Third, there are inherent limitations in manual review, especially for demographic data using only media and textual context. However, in the absence of self-reported information, we believe this method provides an adequate granular view of the campaign information and demographics in MCF evidenced by near-perfect concordance between reviewers. Moreover, we believe our approach parallels the online crowdfunding experience of a potential donor who would rely on his/her perception of a beneficiary's identity and attribute merit based on the illness narrative and media alone.

\section{Conclusions}

We provide a foundational quantitative descriptive analysis of MCF and determinants of success in CAN, the UK, and the US. Despite MCF's exponential growth, a vast majority of campaigns never meet their goal. We highlight important differences in MCF trends in publicly and privately funded healthcare systems, which point to unique gaps in healthcare funding and access in each setting. We also demonstrate racial and gender disparities in the use and success of MCF. MCF directly (through platforms that promote the victim narrative) and indirectly (by rewarding these narratives with funding success) promotes the myth that gaps in healthcare funding are due to misfortune and exceptionality rather than systemic failures. As such, MCF likely entrenches the systemic failures that potentiated its need. Thus, while crowdfunding has the potential to provide short-term relief from medical financial burden for a privileged subset of patients, it carries wider-reach paradoxical societal effect. Further research is needed to understand the social, ethical, and economic implications of MCF within each healthcare setting. 
medRxiv preprint doi: https://doi.org/10.1101/2020.03.26.20044669; this version posted March 30, 2020. The copyright holder for this preprint (which was not certified by peer review) is the author/funder, who has granted medRxiv a license to display the preprint in perpetuity.

It is made available under a CC-BY-NC-ND 4.0 International license.

\section{Acknowledgements}

Availability of data and materials: The data that support the findings of this study are available upon request.

Competing interests: The authors declare that they have no competing interests.

Funding: None.

Authors' contributions:

Study concept and design: SS, EA, RM; Data acquisition and extraction: SS; Data manual review: EA, SS. Manual review adjudication: RM. Data analysis: SS; Interpretation of data: all authors; Manuscript preparation: SS, EA, CL, RM. All authors read and approved the final manuscript. 
medRxiv preprint doi: https://doi.org/10.1101/2020.03.26.20044669; this version posted March 30, 2020. The copyright holder for this preprint (which was not certified by peer review) is the author/funder, who has granted medRxiv a license to display the preprint in perpetuity.

\section{References}

1 Carolyn McClanahan. People Are Raising \$650 Million On GoFundMe Each Year To Attack Rising Healthcare Costs. Forbes. 2018; published online Aug 13. https://www.forbes.com/sites/carolynmcclanahan/2018/08/13/using-gofundme-to-attackhealth-care-costs/\#487dd8052859.

2 Nathan Heller. The Hidden Cost of GoFundMe Health Care. The New Yorker. 2019; published online June 24.

3 Suzanne Woolley. American Health Care Tragedies Are Taking Over Crowdfunding. Bloomberg. 2017; published online June 12. https://www.bloomberg.com/news/articles/201706-12/america-s-health-care-crisis-is-a-gold-mine-for-crowdfunding.

4 Berliner LS, Kenworthy NJ. Producing a worthy illness: Personal crowdfunding amidst financial crisis. Social Science \& Medicine 2017; 187: 233-42.

5 Barney Jopson. Why are so many Americans crowdfunding their healthcare? Financial Times. 2018; published online Jan 10. https://www.ft.com/content/b99a81be-f591-11e7-88f7$5465 \mathrm{a} c \mathrm{ce} 1 \mathrm{a} 00$.

6 Bassani G, Marinelli N, Vismara S. Crowdfunding in healthcare. J Technol Transf 2019; 44: 1290-310.

7 Lukk M, Schneiderhan E, Soares J. Worthy? Crowdfunding the Canadian Health Care and Education Sectors: Health Care and Education Crowdfunding. Canadian Review of Sociology/Revue canadienne de sociologie 2018; 55: 404-24.

8 Sisler J. Crowdfunding for medical expenses. Canadian Medical Association Journal 2012; 184: E123-4.

9 van Duynhoven A, Lee A, Michel R, et al. Spatially exploring the intersection of socioeconomic status and Canadian cancer-related medical crowdfunding campaigns. BMJ Open 2019; 9: e026365.

10The Lancet Oncology. Mind the gap: charity and crowdfunding in health care. The Lancet Oncology 2017; 18: 269.

11 Durand WM, Johnson JR, Eltorai AEM, Daniels AH. Medical Crowdfunding for Patients Undergoing Orthopedic Surgery. Orthopedics 2018; 41: e58-63.

12Durand WM, Peters JL, Eltorai AEM, Kalagara S, Osband AJ, Daniels AH. Medical crowdfunding for organ transplantation. Clin Transplant 2018; 32: e13267.

13 Snyder J, Caulfield T. Patients' crowdfunding campaigns for alternative cancer treatments. The Lancet Oncology 2019; 20: 28-9.

14Cohen AJ, Brody H, Patino G, et al. Use of an Online Crowdfunding Platform for Unmet Financial Obligations in Cancer Care. JAMA Intern Med 2019; 179: 1717.

15 Sirin Kale. When survival is a popularity contest: the heartbreak of crowdfunding healthcare. The Guardian. 2019; published online May 20. https://www.theguardian.com/lifeandstyle/2019/may/20/when-survival-is-a-popularitycontest-the-heartbreak-of-crowdfunding-healthcare.

16Newman M. Is cancer fundraising fuelling quackery? BMJ 2018; : k3829.

17 Vox F, Folkers KM, Turi A, Caplan AL. Medical Crowdfunding for Scientifically

Unsupported or Potentially Dangerous Treatments. JAMA 2018; 320: 1705.

18 Snyder J, Turner L, Crooks VA. Crowdfunding for Unproven Stem Cell-Based Interventions. JAMA 2018; 319: 1935.

19 Young MJ, Scheinberg E. The Rise of Crowdfunding for Medical Care: Promises and Perils. JAMA 2017; 317: 1623. 
medRxiv preprint doi: https://doi.org/10.1101/2020.03.26.20044669; this version posted March 30, 2020. The copyright holder for this preprint (which was not certified by peer review) is the author/funder, who has granted medRxiv a license to display the preprint in perpetuity. It is made available under a CC-BY-NC-ND 4.0 International license .

20 Ainsley Harris. GoFundMe keeps gobbling up competitors, says it's 'very good for the market'. Fast Company. 2018; published online April 4.

https://www.fastcompany.com/40554199/gofundme-keeps-gobbling-up-competitors-says-itsvery-good-for-the-market.

21 BeautifulSoup. https://www.crummy.com/software/BeautifulSoup/bs4/.

22 Landis JR, Koch GG. The measurement of observer agreement for categorical data.

Biometrics 1977; 33: 159-74.

23 Statistics Canada. Canada [Country] and Canada [Country] (table). Census Profile. 2016 Census. 2017; published online Nov 29. https://www12.statcan.gc.ca/censusrecensement/2016/dp-pd/prof/index.cfm?Lang=E.

24Office for National Statistics. Estimates of the population for the UK, England and Wales, Scotland and Northern Ireland. 2019; published online June 26. https://www.ons.gov.uk/peoplepopulationandcommunity/populationandmigration/populatione stimates/datasets/populationestimatesforukenglandandwalesscotlandandnorthernireland.

25 U.S. Census Bureau. Annual County Resident Population Estimates by Age, Sex, Race, and Hispanic Origin. 2019; published online June 20. https://www.census.gov/newsroom/presskits/2019/detailed-estimates.html.

26Rachel Monroe. When GoFundMe Gets Ugly. The Atlantic. 2019; published online Nov. https:/www.theatlantic.com/magazine/archive/2019/11/gofundme-nation/598369/.

27 Kenworthy N, Dong Z, Montgomery A, Fuller E, Berliner L. A cross-sectional study of social inequities in medical crowdfunding campaigns in the United States. PLoS ONE 2020; 15: e0229760.

28 Kubota JT, Li J, Bar-David E, Banaji MR, Phelps EA. The Price of Racial Bias: Intergroup Negotiations in the Ultimatum Game. Psychol Sci 2013; 24: 2498-504.

29 Snyder J, Mathers A, Crooks VA. Fund my treatment!: A call for ethics-focused social science research into the use of crowdfunding for medical care. Social Science \& Medicine 2016; 169: 27-30.

30 Snyder J. Crowdfunding FOR MEDICAL CARE: Ethical Issues in an Emerging Health Care Funding Practice. Hastings Center Report 2016; 46: 36-42.

31 Robin A. Cohen, Emily Terlizzi, Michael Martinez. Health Insurance Coverage: Early Release of Estimates From the National Health Interview Survey, 2018. National Center for Health Statistics, Centers for Disease Control and Prevention, 2019.

32 Sara R. Collins, Herman K. Bhupal, Michelle M. Doty. Health Insurance Coverage Eight Years After the ACA: Fewer Uninsured Americans and Shorter Coverage Gaps, But More Underinsured. Commonwealth Fund, 2019.

332019 Employer Health Benefits Survey. Kaiser Family Foundation, 2019 https://www.kff.org/health-costs/report/2019-employer-health-benefits-survey/.

34Rice T, Quentin W, Anell A, et al. Revisiting out-of-pocket requirements: trends in spending, financial access barriers, and policy in ten high-income countries. BMC Health Serv Res 2018; 18: 371.

35 Altice CK, Banegas MP, Tucker-Seeley RD, Yabroff KR. Financial Hardships Experienced by Cancer Survivors: A Systematic Review. JNCI J Natl Cancer Inst 2017; 109: djw205.

36 Aggarwal A, Sullivan R. Affordability of cancer care in the United Kingdom - Is it time to introduce user charges? Journal of Cancer Policy 2014; 2: 31-9. 
medRxiv preprint doi: https://doi.org/10.1101/2020.03.26.20044669; this version posted March 30, 2020. The copyright holder for this preprint

(which was not certified by peer review) is the author/funder, who has granted medRxiv a license to display the preprint in perpetuity.

It is made available under a CC-BY-NC-ND 4.0 International license .

37 Sam D, Cheung WY. A population-level comparison of cancer-related and non-cancer-related health care costs using publicly available provincial administrative data. Curr Oncol 2019; 26. DOI: $10.3747 /$ co.26.4399.

38 Gilligan AM, Alberts DS, Roe DJ, Skrepnek GH. Death or Debt? National Estimates of Financial Toxicity in Persons with Newly-Diagnosed Cancer. The American Journal of Medicine 2018; 131: 1187-1199.e5.

39Cordova A, Dolci J, Gianfrate G. The Determinants of Crowdfunding Success: Evidence from Technology Projects. Procedia - Social and Behavioral Sciences 2015; 181: 115-24.

40Zhou M, Lu B, Fan W, Wang GA. Project description and crowdfunding success: an exploratory study. Inf Syst Front 2018; 20: 259-74.

41 Snyder J, Crooks VA, Mathers A, Chow-White P. Appealing to the crowd: ethical justifications in Canadian medical crowdfunding campaigns. J Med Ethics 2017; 43: 364-7. 
medRxiv preprint doi: https://doi.org/10.1101/2020.03.26.20044669; this version posted March 30, 2020. The copyright holder for this preprint (which was not certified by peer review) is the author/funder, who has granted medRxiv a license to display the preprint in perpetuity.

\section{It is made available under a CC-BY-NC-ND 4.0 International license .}

Figure 1. Study flow diagram.

Scraped campaigns in CA, UK, and US on $2 / 26 / 2019(n=3,000)$

New scraped campaigns in CA, UK, and US on 3/30/2019 ( $n=457)$

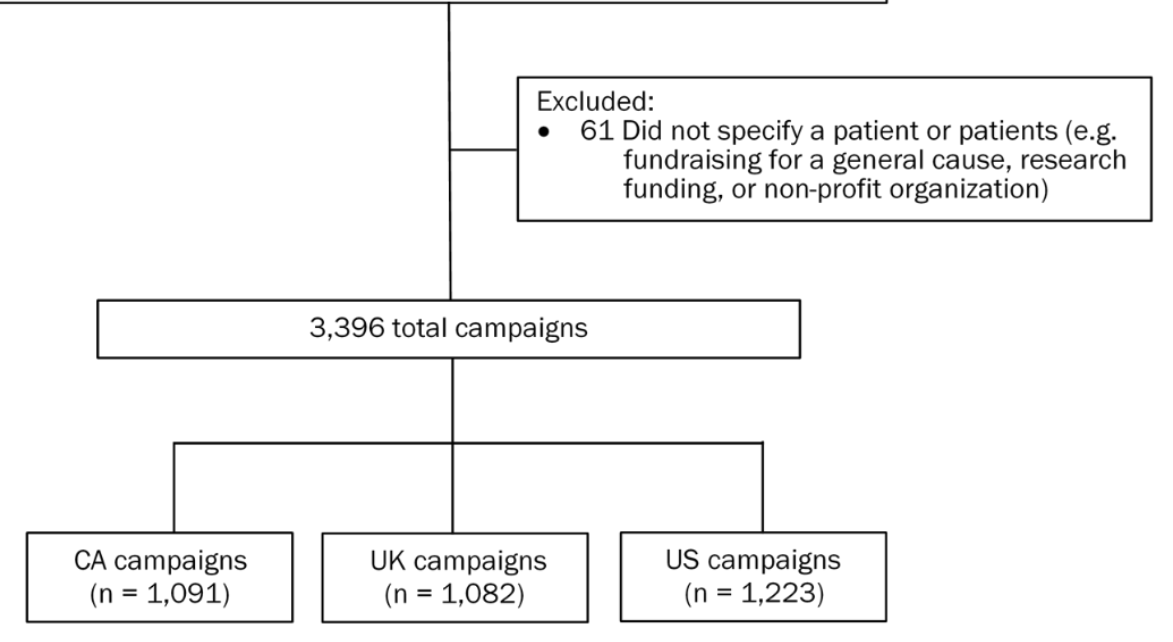


medRxiv preprint doi: https://doi.org/10.1101/2020.03.26.20044669; this version posted March 30, 2020. The copyright holder for this preprint (which was not certified by peer review) is the author/funder, who has granted medRxiv a license to display the preprint in perpetuity.

It is made available under a CC-BY-NC-ND 4.0 International license .

Table 1. Baseline characteristics stratified by country for entire cohort. Continuous variables presented as median (IQR), categorical variables as number (\%).

Age Group, No. (\%)

Adult (> 18y)

Minor (2 - 18y)

Infant $(<2 y)$

$>1$ age group ${ }^{a}$

Gender, No. (\%)

Male

Female

Transgender

$>1$ gender $^{\mathrm{a}}$

Race, No. (\%)

Black

Not black

Beneficiary outside country, No. $(\%)^{\text {b }}$

Diagnosis, No. (\%)

Acute illness

Cancer

Cardiac

Neurologic

Transplant

Trauma

Other

Fundraising

Goal, median (IQR), \$ US ${ }^{\mathrm{c}}$

Raised, median (IQR), \$ US ${ }^{\mathrm{c}}$

Donors, median (IQR)

Primarily funding treatment, No. $(\%)^{d}$

Campaign Information

Facebook shares, median (IQR)

GoFundMe hearts, median (IQR)

Fundraising length, median (IQR), months

Narrative, median (IQR), words

Narrative, median (IQR), characters

\section{All Canada}

\begin{tabular}{|c|c|c|c|c|}
\hline $\begin{array}{c}\text { All } \\
n=3,396 \\
\end{array}$ & $\begin{array}{c}\text { Canada } \\
\mathrm{n}=\mathbf{1 , 0 9 1}\end{array}$ & $\begin{array}{c}\text { United Kingdom } \\
\mathrm{n}=\mathbf{1 , 0 8 2} \\
\end{array}$ & $\begin{array}{c}\text { United States } \\
\mathrm{n}=\mathbf{1 , 2 2 3} \\
\end{array}$ & $\mathbf{p}$ \\
\hline $2583(76.1)$ & 803 (73.6) & $813(75.1)$ & $967(79.1)$ & 0.006 \\
\hline $604(17.8)$ & $213(19.5)$ & $212(19.6)$ & $179(17.8)$ & 0.002 \\
\hline $139(4.1)$ & $60(5.5)$ & $34(3.1)$ & $45(4.1)$ & 0.01 \\
\hline $70(2.1)$ & $15(1.4)$ & $23(2.1)$ & $32(2.6)$ & 0.11 \\
\hline $1767(52.0)$ & $553(50.7)$ & $492(45.5)$ & $722(59.0)$ & $<0.001$ \\
\hline $1540(45.3)$ & $521(47.8)$ & $550(50.8)$ & $469(38.4)$ & $<0.001$ \\
\hline $14(0.4)$ & $0(0.0)$ & $14(1.3)$ & $0(0.0)$ & $<0.001$ \\
\hline $75(2.2)$ & $17(1.6)$ & $26(2.4)$ & $32(2.6)$ & 0.20 \\
\hline $3255(95.8)$ & $21(1.9)$ & $55(5.1)$ & $65(5.3)$ & \\
\hline $141(4.2)$ & $1070(98.1)$ & $1026(94.9)$ & $1158(94.7)$ & $<0.001$ \\
\hline $140(4.1)$ & $30(2.7)$ & $105(9.7)$ & $6(0.5)$ & $<0.001$ \\
\hline $124(3.7)$ & $34(3.1)$ & $31(2.9)$ & $59(4.8)$ & 0.02 \\
\hline $1850(54.5)$ & $659(60.4)$ & $532(49.2)$ & $659(53.9)$ & $<0.001$ \\
\hline $108(3.2)$ & $19(1.7)$ & $33(3.0)$ & $56(4.6)$ & $<0.001$ \\
\hline $521(15.3)$ & $158(14.5)$ & $218(20.1)$ & 145 (11.9) & $<0.001$ \\
\hline $108(3.2)$ & $45(4.1)$ & $17(1.6)$ & $46(3.8)$ & 0.001 \\
\hline $332(9.8)$ & $90(8.2)$ & $70(6.5)$ & $172(14.1)$ & $<0.001$ \\
\hline $353(10.4)$ & $86(7.9)$ & $181(16.7)$ & $86(7.0)$ & $<0.001$ \\
\hline $\begin{array}{c}30,000 \\
(11,400-57,000)\end{array}$ & $\begin{array}{c}19,000 \\
(10,260-38,000)\end{array}$ & $\begin{array}{c}13,200 \\
(5,534-33,396)\end{array}$ & $\begin{array}{c}50,000 \\
(35,000-100,000)\end{array}$ & $<0.001$ \\
\hline 18,505 & 12,662 & 6,285 & 38,204 & $<0.001$ \\
\hline$(8,570-36,052)$ & $(9,377-19,251)$ & $(4,028-12,348)$ & $(31,200-52,123)$ & -0.001 \\
\hline $\begin{array}{c}190 \\
(106-332)\end{array}$ & $\begin{array}{c}153 \\
(104-232)\end{array}$ & $\begin{array}{c}110 \\
(68-194)\end{array}$ & $\begin{array}{c}321 \\
(222-498)\end{array}$ & $<0.001$ \\
\hline $1079(31.8)$ & $251(23.0)$ & $478(44.2)$ & 349 (28.5) & $<0.001$ \\
\hline $632(306-1,100)$ & $565(316-926)$ & $386(174-808)$ & $1000(547-1,700)$ & $<0.001$ \\
\hline $187(104-331)$ & $155(103-232)$ & $109(67-191)$ & $322(222-506)$ & $<0.001$ \\
\hline $4(1-6)$ & $5(2-8)$ & $5(1-8)$ & $3(1-4)$ & $<0.001$ \\
\hline $317(193-512)$ & $321(201-509)$ & $343(193-566)$ & $301(188-478)$ & 0.003 \\
\hline $\begin{array}{c}1,844 \\
(1,118-2.978)\end{array}$ & $\begin{array}{c}1,884 \\
(1,172-2,983)\end{array}$ & $\begin{array}{c}1,942 \\
(1,090-3,256)\end{array}$ & $\begin{array}{c}1,762 \\
(1,091-2,819)\end{array}$ & 0.02 \\
\hline
\end{tabular}

${ }^{\mathrm{a}}$ More than one beneficiary was included in the same campaign so no singular age and/or gender could be identified.

${ }^{\mathrm{b}}$ Beneficiary lives in a different country than the campaigning country (e.g. Canadian campaign raising funds for family member in the Philippines).

${ }^{c}$ All monetary values were converted to US dollars based on currency exchange rates at the time the data was accessed.

${ }^{\mathrm{d}}$ Campaign clearly identifies that its primary funding goal is for medical treatment. See eAppendix in the Supplement details. 
medRxiv preprint doi: https://doi.org/10.1101/2020.03.26.20044669; this version posted March 30, 2020. The copyright holder for this preprint (which was not certified by peer review) is the author/funder, who has granted medRxiv a license to display the preprint in perpetuity.

It is made available under a CC-BY-NC-ND 4.0 International license.

Table 2. Comparison of the proportion of campaign representation to the proportion of population according to national census data (2016 CAN, 2018 UK, 2018 US). Campaigns with more than one beneficiary were excluded.

Canada

United Kingdom

United States

\begin{tabular}{|c|c|c|c|c|c|c|c|c|c|}
\hline & $\begin{array}{c}\text { Campaign } \\
\text { n (\%) }\end{array}$ & $\begin{array}{c}\text { Census } \\
\%\end{array}$ & $\mathbf{p}^{\mathbf{a}}$ & $\begin{array}{c}\text { Campaign } \\
\text { n (\%) }\end{array}$ & $\begin{array}{c}\text { Census } \\
\%\end{array}$ & $\mathbf{p}^{\mathbf{a}}$ & $\begin{array}{c}\text { Campaign } \\
\text { n }(\%)\end{array}$ & $\begin{array}{c}\text { Census } \\
\%\end{array}$ & $\mathbf{p}^{\mathbf{a}}$ \\
\hline \multicolumn{10}{|l|}{ Age Group, No. (\%) } \\
\hline Adult $(>18 y)$ & $803(74.8)$ & 80.0 & $<0.001$ & $813(76.8)$ & 78.8 & 0.11 & 967 (81.2) & 77.6 & 0.003 \\
\hline Minor (2-18y) & $213(19.8)$ & 17.9 & 0.11 & $212(20.0)$ & 18.9 & 0.36 & $179(15.0)$ & 20.1 & $<0.001$ \\
\hline Infant $(<2 y)$ & $60(5.6)$ & 2.1 & $<0.001$ & $34(3.2)$ & 2.3 & 0.03 & $45(3.8)$ & 2.4 & 0.002 \\
\hline \multicolumn{10}{|l|}{ Gender, No. (\%) } \\
\hline Male & $553(51.5)$ & 49.1 & 0.13 & $492(47.2)$ & 49.3 & 0.18 & $722(60.6)$ & 49.2 & $<0.001$ \\
\hline Female & $521(48.5)$ & 50.9 & 0.13 & $550(52.8)$ & 50.7 & 0.18 & $469(39.4)$ & 50.8 & $<0.001$ \\
\hline \multicolumn{10}{|l|}{ Race, No (\%) } \\
\hline Black & $21(1.9)$ & 3.5 & & $55(5.1)$ & 3.1 & & $65(5.3)$ & 13.4 & \\
\hline Not black & $1070(98.1)$ & 96.5 & 0.007 & $1026(94.9)$ & 96.9 & $<0.001$ & $1158(94.7)$ & 86.6 & $<0.001$ \\
\hline
\end{tabular}

${ }^{\mathrm{a}}$ The p-value is determined by using Chi-squared testing to compare the proportion of campaign representation to the proportion of the national census in each country. 
medRxiv preprint doi: https://doi.org/10.1101/2020.03.26.20044669; this version posted March 30, 2020. The copyright holder for this preprint (which was not certified by peer review) is the author/funder, who has granted medRxiv a license to display the preprint in perpetuity.

It is made available under a CC-BY-NC-ND 4.0 International license .

Figure 2. Primary type of treatment by country for A) all campaigns and B) for campaigns primarily for treatment costs.

A.

\section{All Campaigns}
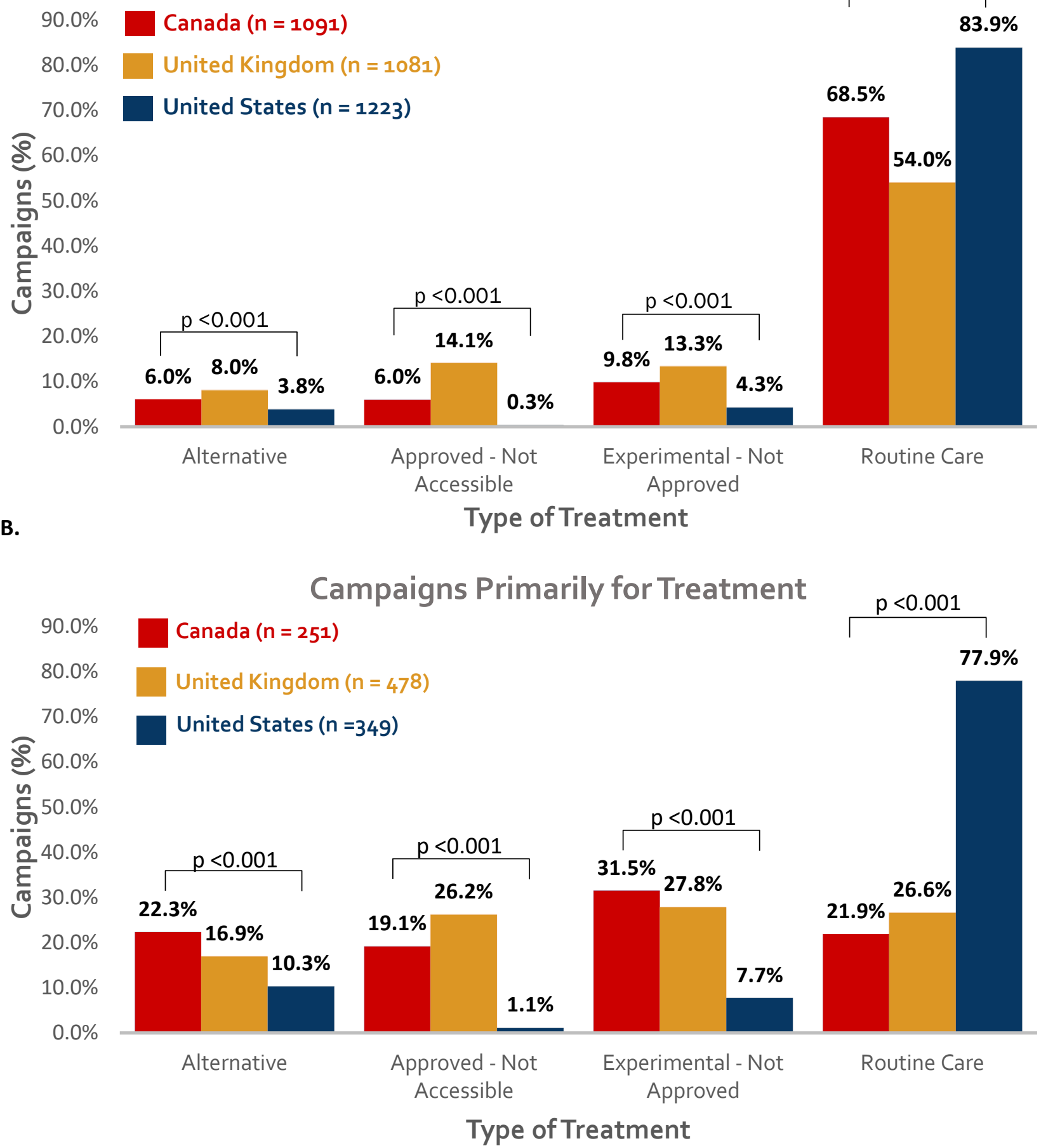
medRxiv preprint doi: https://doi.org/10.1101/2020.03.26.20044669; this version posted March 30, 2020. The copyright holder for this preprint (which was not certified by peer review) is the author/funder, who has granted medRxiv a license to display the preprint in perpetuity. It is made available under a CC-BY-NC-ND 4.0 International license .

Table 3. Multivariable linear regression for amount raised for the full cohort and for each country. Values reflect linear regression coefficient and 95\% CI for each variable after adjustment for all other variables listed in the table.

\begin{tabular}{ccc}
\hline & \multicolumn{2}{c}{ Linear Regression Coefficients (95\% CI) } \\
\hline All & Canada & United Kingdom
\end{tabular}

$\begin{array}{lllll}\left(R^{2}=0.67\right) & p & \left(R^{2}=0.40\right) & p & \left(R^{2}=0.68\right)\end{array}$
Demographics/Location

$\begin{array}{ccc}\text { United States } \\ \left(\mathbf{R}^{2}=\mathbf{0 . 5 3}\right) & \mathbf{p}\end{array}$

$\begin{array}{lll}\left(R^{2}=0.68\right) & p & \left(R^{2}=0.53\right)\end{array}$

0.11

384
$(-1,699$ to 2,680$)$

$0.72 \quad \begin{gathered}1,733 \\ -412 \text { to } 3,878)\end{gathered}$

0.11

Transgender $\begin{gathered}-2,129 \\ (-11,200 \text { to } 6,902)\end{gathered}$

Adult $\quad \begin{gathered}780 \\ (-674 \text { to } 2,234)\end{gathered}$

$0.65 \quad$ N/A

$-4,031$

$(13,300$ to 5,267$)$

28.4

$0.29 \quad \begin{array}{cc}193 \\ (-1,867 \text { to } 2,254)\end{array}$

$(-2,456$ to 2,513$)$

0.40

N/A

$0.98 \quad 1,238$

$(-1,623$ to 4,098$)$

0.40

Infant

$-1,800$

$0.26-2,857$

$(-6,813$ to 1,099$)$

0.16

$-3,027$

$(-9,142$ to 3,088$)$

0.33

2,053

$(-4,012$ to 8,118$)$

0.51

Black $\begin{gathered}-4,007 \\ (-6,913 \text { to }-1,101)\end{gathered}$

$0.007 \quad \begin{array}{cc}-4,639 \\ (-10,500 \text { to } 1,232)\end{array}$

$-4,454$

(-9309 to 400)

0.07

$-2,879$

$(-7,606$ to 1,849$)$

0.23

$\begin{array}{cc}\text { Canadian } & -2,419 \\ \text { campaign } & (-3,757 \text { to }-1,081)\end{array}$

$<0.001 \quad$ N/A

N/A

$--\quad$ N/A

N/A

N/A

(18,400)

$<0.001$

N/A

$<0.001$

N/A

Non-Medicaid

expansion

$$
\begin{aligned}
& \text { N/A } \\
& -70.9
\end{aligned}
$$

$--\quad$ N/A

outside country ${ }^{\text {a }}$

Beneficiary

deceased

$(-3,185$ to 3,043$)$

$-3,031$

$(-6,889$ to 828$)$

$0.96-3,042$

$\begin{array}{ccc} & (-8284 \text { to } 2,200) \\ 0.12 & 2,315 & 0.26 \\ & (-4,345 \text { to } 8,975) & 0.50\end{array}$

0.26
0.50

N/A

676

$(-3,476$ to 4,829$)$

$-2,620$

$(-9,635$ to 4,396$)$

$--\quad$ N/A

-- $\quad$ N/A

1,469

-- $\quad(-933$ to 3,870$)$

0.23

0.75

$-5,853$

$(-20,900$ to 9,154$)$

0.44

$0.46 \quad-(-12,300$ to 69.2$)$

0.05

\begin{tabular}{|c|c|c|c|c|c|c|c|c|}
\hline Acute illness & $\begin{array}{c}-1,697 \\
(-5,719 \text { to } 2,325)\end{array}$ & 0.41 & $\begin{array}{c}-2,579 \\
(-7,650 \text { to } 2,492)\end{array}$ & 0.32 & $\begin{array}{c}-433 \\
(-6,389 \text { to } 5,523)\end{array}$ & 0.89 & $\begin{array}{c}-4,471 \\
(-10,600 \text { to } 1,658)\end{array}$ & 0.15 \\
\hline Cancer & $\begin{array}{c}2,379 \\
(-1,121 \text { to } 5,878)\end{array}$ & 0.18 & $\begin{array}{c}1,593 \\
(-1,347 \text { to } 4,533)\end{array}$ & 0.29 & $\begin{array}{c}340 \\
(-2,556 \text { to } 3,236)\end{array}$ & 0.82 & $\begin{array}{c}1,726 \\
(-3,474 \text { to } 6,925)\end{array}$ & 0.52 \\
\hline Cardiac & $\begin{array}{c}3,799 \\
(-215 \text { to } 7,812)\end{array}$ & 0.06 & $\begin{array}{c}806 \\
(-5,624 \text { to } 7,236)\end{array}$ & 0.81 & $\begin{array}{c}2,349 \\
(-3,888 \text { to } 8,586)\end{array}$ & 0.46 & $\begin{array}{c}4,517 \\
(-1,551 \text { to } 10,600)\end{array}$ & 0.14 \\
\hline Neurologic & $\begin{array}{c}2,389 \\
(-1,106 \text { to } 5.884)\end{array}$ & 0.18 & $\begin{array}{c}-1,000 \\
(-4,319 \text { to } 2,319)\end{array}$ & 0.56 & $\begin{array}{c}1,613 \\
(-1,666 \text { to } 4,892)\end{array}$ & 0.34 & $\begin{array}{c}4,350 \\
(-1,063 \text { to } 9,762)\end{array}$ & 0.12 \\
\hline Transplant & $\begin{array}{c}-451 \\
(-4,214 \text { to } 3,312)\end{array}$ & 0.81 & $\begin{array}{c}-1,704 \\
(-6,114 \text { to } 2,705)\end{array}$ & 0.45 & $\begin{array}{c}1,885 \\
(-5,650 \text { to } 9,421)\end{array}$ & 0.62 & $\begin{array}{c}316 \\
(-5,088 \text { to } 5,720)\end{array}$ & 0.91 \\
\hline Trauma & $\begin{array}{c}1,156 \\
(-2,720 \text { to } 5,033)\end{array}$ & 0.56 & $\begin{array}{c}990 \\
(-3,048 \text { to } 5,027)\end{array}$ & 0.63 & $\begin{array}{c}-915 \\
(-5,587 \text { to } 3,756)\end{array}$ & 0.70 & $\begin{array}{c}2,343 \\
(-3,343 \text { to } 8,029)\end{array}$ & 0.42 \\
\hline
\end{tabular}

Diagnosis

Treatment Type/Details

Alternative

$-1,709$

$(-4,156$ to 739$)$

23

Approved - not

accessible

$(-2,852$ to 2,899$)$
$0.17 \quad-979$

$(-4,448$ to 2,489$)$

3,247

0.99

$(-953$ to 7,447$)$

0.58

0.13
$-126$

$(-4,330$ to 4,078$)$

$-1,238$

$(-5,315$ to 2,840$)$
0.95

$(-10,200$ to -525$)$

17,390

0.55
0.03

0.07 
medRxiv preprint doi: https://doi.org/10.1101/2020.03.26.20044669; this version posted March 30, 2020. The copyright holder for this preprint (which was not certified by peer review) is the author/funder, who has granted medRxiv a license to display the preprint in perpetuity.

It is made available under a CC-BY-NC-ND 4.0 International license .

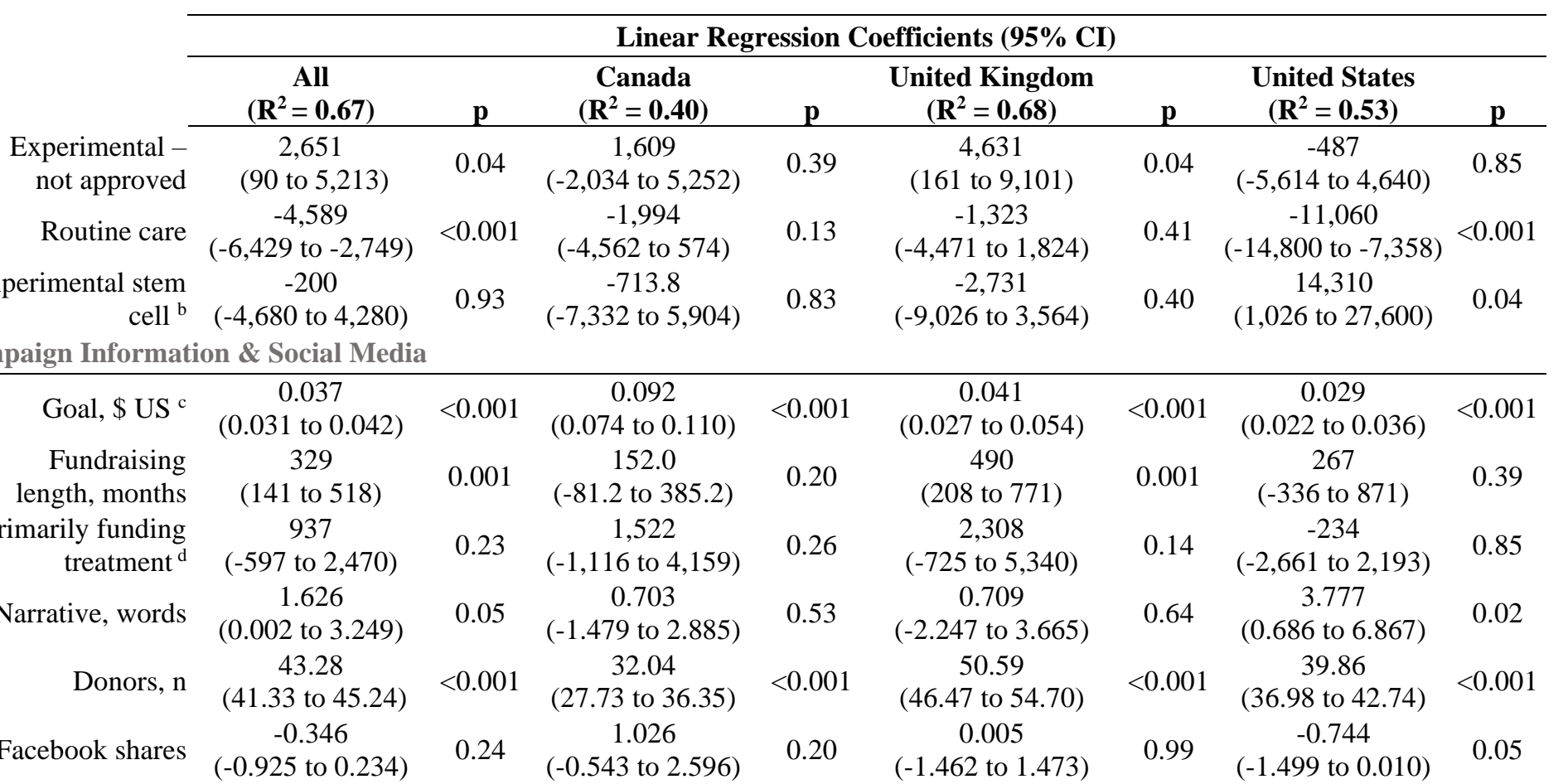

${ }^{a}$ Beneficiary of the campaign lives in a different country than a campaigning country (e.g Canadian campaign raising funds for family member in the Philippines).

${ }^{\mathrm{b}}$ Campaign mentions stem cell treatment or transplant in an experimental application (i.e. not for leukemias, lymphomas, etc.).

${ }^{\mathrm{c}}$ All monetary values were converted to US dollars based on currency exchange rates at the time the data was accessed.

${ }^{\mathrm{b}}$ Campaign clearly identifies that its primary funding goal is for medical treatment. See eAppendix in the Supplement for details. 